\title{
A mentor-mentee support program for people with anorexia nervosa
}

\author{
Lucie Ramjan ${ }^{1 *}$, Sarah Fogarty ${ }^{1}$, Daniel Nicholls', Phillipa Hay ${ }^{2}$ \\ From 2015 ANZAED Conference: Riding the Waves to Recovery \\ Surfers Paradise, Australia. 21-22 August 2015
}

\section{Background}

Successful mentorship enhances quality of life, hope for recovery and empowers people with anorexia nervosa (AN) to develop health-promoting strategies, with immeasurable benefits for both mentor and mentee.

\section{Aims}

To develop and evaluate, in consultation with stakeholders (people with AN and recovered individuals), a mentorship support program for people with AN in NSW.

\section{Methods}

This study is a mixed methods participatory action research (PAR) project. Participants are pivotal in the development and design of a tailored program. Researchers work closely with stakeholders to bring and evaluate change, through cycles of learning and reflection, actively engaging participants in the research process.

\section{Results}

During workshop discussions, participants (4 mentors and 5 mentees) defined the program, examined roles and responsibilities, partnerships, interaction, use of funds, conflict resolution and risk management. The workshop, conducted informally in a setting that simulated a home environment, reduced anxiety levels. Uncertainty evolved into an appreciation for the program, development of new relationships, learning that everyone had similar reservations yet reassurance that people were there to support and encourage recovery. Participants were positive and optimistic for the program's trial.

\section{Conclusion}

PAR is an apt research method for actively engaging stakeholders in the development of a tailored program to support recovery.

\section{Authors' details}

${ }^{1}$ School of Nursing and Midwifery; University of Western Sydney, Australia.

${ }^{2}$ School of Medicine; University of Western Sydney, Australia.

Published: 23 November 2015

doi:10.1186/2050-2974-3-S1-045

Cite this article as: Ramjan et al:: A mentor-mentee support program for people with anorexia nervosa. Journal of Eating Disorders 2015 3(Suppl 1): 045 .

* Correspondence: I.ramjan@westernsydney.edu.au

${ }^{1}$ School of Nursing and Midwifery; University of Western Sydney, Australia Full list of author information is available at the end of the article

Submit your next manuscript to BioMed Central and take full advantage of:

- Convenient online submission

- Thorough peer review

- No space constraints or color figure charges

- Immediate publication on acceptance

- Inclusion in PubMed, CAS, Scopus and Google Scholar

- Research which is freely available for redistribution
() Biomed Central
C Biomed Central (c) 2015 Ramjan et al. This is an Open Access article distributed under the terms of the Creative Commons Attribution License (http://
creativecommons.org/licenses/by/4.0), which permits unrestricted use, distribution, and reproduction in any medium, provided the original work is properly cited. The Creative Commons Public Domain Dedication waiver (http://creativecommons.org/publicdomain/ zero/1.0/) applies to the data made available in this article, unless otherwise stated. 